\title{
POTENSI CANGKANG BUAH NYAMPLUNG (Calophyllum inophyllum) SEBAGAI SUMBER RESIN ALAMI
}

\section{POTENCY OF CALOPHYLLUM FRUIT SHELL AS NATURAL RESIN SOURCE}

\author{
Ika Amalia Kartika ${ }^{1 *}$, Rafiq Izzudin Rabbani ${ }^{1)}$, dan Nancy Dewi Yuliana ${ }^{2)}$ \\ ${ }^{1)}$ Departemen Teknologi Industri Pertanian, FATETA-IPB University \\ Kampus IPB Dramaga P.O. Box 220, Bogor 16680, Indonesia \\ Tel.: +62 $2518621974 ;+622518621974$. \\ Email: ikatk@yahoo.com \\ ${ }^{2)}$ Departemen Ilmu dan Teknologi Pangan, FATETA-IPB University \\ Makalah: Diterima 4 September 2019; Diperbaiki 16 November 2019; Disetujui 30 November 2019
}

\begin{abstract}
The objective of this work is to extract the resin from Calophyllum fruit shell, and to investigate the effect of solvent type (ethanol and methanol), shell to solvent ratio (1:6 and 1:8)and temperature (30, 40 and $50^{\circ} \mathrm{C}$ ) on resin yield and its property. The experimentation was done using randomized factorial design.In general, solvent type, shell to solvent ratio and temperature affected resin yield and its property. Based on the variance analysis results $(\alpha=0.05)$, the effect of temperature and shell to solvent ratio on resin yield was more evidential than solvent type.The higher the ratio of shell to solvent and the temperature, the resin yield was also increasing. The highest resin yield $(7.69 \%$ or $75.32 \%$ based on potential mass of resin contained in Calophyllum shell) wasobtained at a shell to solvent ratio of $1: 8$ and a temperature of $50^{\circ} \mathrm{C}$ with methanol as solvent.The effect of process conditions was very noticeable on total phenol content of resin, while its acid value was only significantly affected by solvent type andshell to solvent ratio. An increase in shell to solvent ratio and temperature improved total phenol content of resin.The highest total phenol content (71.23 $\mathrm{mg}$ gallic acid equivalent $/ \mathrm{kg}$ ) was obtained at 1:8 of shell to solvent ratio and $30^{\circ} \mathrm{C}$ with methanol as solvent. Acid value of resin ranged from 112-145 $\mathrm{mg} \mathrm{KOH/g}$, and it positively contained saponins.Calophyllum fruit shell had thus great potential as a natural resin source.
\end{abstract}

Keywords: Calophyllum, ethanol, extraction, fruit shell, methanol, resin

\section{ABSTRAK}

Penelitian ini bertujuan untuk mengekstraksi resin dari cangkang buah nyamplung (Calophyllum inophyllum), dan untuk menginvestigasi pengaruh jenis pelarut (etanol dan metanol), rasio bahan terhadap pelarut (1:6 dan 1:8) dan suhu ekstraksi $\left(30,40\right.$ dan $\left.50^{\circ} \mathrm{C}\right)$ terhadap rendemen resin dan karakteristiknya sehingga diperoleh kondisi proses ekstraksi terbaik. Penelitian dilakukan menggunakan rancangan acak lengkap faktorial, dan dianalisis menggunakan analisis ragam (ANOVA) pada $\alpha=0,05$. Secara umum jenis pelarut, nisbah cangkang terhadap pelarut dan suhu ekstraksi mempengaruhi rendemen dan karakteristik resin yang dihasilkan. Hasil sidik ragam $(\alpha=0.05)$ menunjukkan pengaruh nisbah cangkang terhadap pelarut dan suhu ekstraksi pada rendemen resin lebih nyata daripada jenis pelarut. Semakin tinggi nisbah cangkang terhadap pelarut dan suhu ekstraksi, rendemen resin juga semakin meningkat. Rendemen resin tertinggi $(7,69 \%$ atau $75,32 \%$ basis massa resin potensial yang dikandung bahan)dengan demikian diperoleh dari proses ekstraksi dengan pelarut metanol pada rasio bahan terhadap pelarut $1: 8$ dan suhu $50^{\circ} \mathrm{C}$. Pengaruh ketiga faktor proses sangat nyata teramati pada kadar total fenol resin, sedangkan bilangan asam resin hanya dipengaruhi secara nyata oleh rasio bahan terhadap pelarut dan jenis pelarut. Semakin rendah rasio bahan terhadap pelarut dan suhu ekstraksi, kadar total fenol resin semakin tinggi. Kadar total fenol tertinggi (71,23 mg ekuivalen asam galat $/ \mathrm{kg})$ diperoleh dari proses ekstraksi dengan pelarut metanol pada rasio bahan terhadap pelarut $1: 8$ dan suhu $30^{\circ} \mathrm{C}$. Bilangan asam resin yang diperoleh pada penelitian berkisar antara 112-145 $\mathrm{mg} \mathrm{KOH} / \mathrm{g}$, dan resin positif mengandung saponin. Cangkang buah nyamplung jadi memiliki potensi yang besar sebagai penghasil resin alami.

Kata kunci: nyamplung, etanol, ekstraksi, cangkang, metanol, resin

\section{PENDAHULUAN}

Cangkang buah nyamplung (Calophyllum inophyllum) merupakan limbah hasil dari pengolahan buah nyamplung. Tanaman nyamplung dapat menghasilkan 20 ton buah/ha per tahun, dan luas tegakan tanaman nyamplung di Indonesia sekitar 255.350 ha yang tertebar di Jawa, Jambi, Sumatera Barat dan Selatan, Riau, Maluku, Lampung, Kalimantan Barat dan Tengah, NTT, Sulawesi, dan Papua (Bustomi et al., 2014). Pada saat ini buah nyamplung banyak diolah menjadi 
minyak melalui proses ekstraksi, dan pemanfaatan minyak nyamplung umumnya untuk keperluan non pangan (seperti untuk sabun, pelitur, minyak rambut, pelapis, minyak urut), kosmetika dan farmasi (Atabani dan César, 2014), serta biofuel dan biodiesel (Jain et al., 2018). Bagian dari buah nyamplung yang banyak diolahdalam proses ekstraksi adalah bijinya. Hal itu karena biji nyamplung memiliki kadar minyak yang tinggi (>50\% bk) (Kartika et al.,2 018). Berdasarkan hasil penelitian Kartika et al. (2017), buah nyamplung tersusun atas $60 \%$ cangkang dan $40 \%$ biji, artinya dari $1 \mathrm{~kg}$ buah nyamplung dihasilkan $0,6 \mathrm{~kg}$ cangkang buah nyamplung. Besarnya jumlah produksi cangkang buah nyamplung ini sayangnya belum dimanfaatkan secara maksimal. Pemanfaatan cangkang buah nyamplung sampai saat ini baru sampai pada tahap pengolahan cangkang menjadi pupuk organik atau briket padahal potensi pemanfaatan resin yang terkandung didalamnya untuk diolah menjadi produk-produk bernilai tambah tinggi sangatlah besar (Leksono et al., 2014).

Resin merupakan bahan amorf yang tersusun atas bahan kimia alam yang kompleks. Secara fisik resin biasanya keras atau kental, larut dalam pelarut organik seperti alkohol tetapi tidak larut dalam air, serta meleleh ketika dipanaskan (Frial-McBride, 2016). Resin yang berasal dari nyamplung teksturnya sangat kental dan berwarna hijau kehitaman. Menurut Liu et al. (2015), resin nyamplung ini dapat digunakan untuk mengobati odontalgia dan pendarahan gusi. Kalofiloid, flavonoid, kumarin, inofilum A-E, triterpen, keton, asam kalofinat dan begonia, xanton, serta fenol dan polifenol merupakan senyawa-senyawa yang umumnya ditemukan dalam resin nyamplung (Dweck dan Meadows, 2002), selain polimer proantisoanidin (Tempesta, 1993).

Resin dapat diekstraksi dari berbagai tanaman menggunakan pelarut-pelarut polar seperti metanol, etanol (Assagaf et al., 2012; Liu et al., 2015; Kartika et al., 2017; Susanto et al., 2017; Amalia Kartika et al., 2018). Faktor-faktor yang perlu dipertimbangkan dalam proses ekstraksi selain jenis pelarut dan kondisi prosesnya adalah jumlah pelarut,ukuran bahan dan persiapannya sebelum ekstraksi (Swern, 1982). Komposisi pelarut, nisbah bahan terhadap pelarut, suhu dan waktu ekstraksi juga merupakan faktor-faktor yang perlu diperhatikan untuk meningkatkan efisiensi proses ekstraksi (Assagaf et al., 2012). Atas dasar itu, studi tentang ekstraksi resin dari cangkang buah nyamplung perlu dilakukan untuk mendapatkan rendemen dan karakteristiknya yang optimal. Tujuan penelitian ini adalah untuk mengetahui potensi cangkang buah nyamplung sebagai sumber resin alami dengan menganalisis pengaruh jenis pelarut (etanol dan metanol), nisbah cangkang terhadap pelarut (1:6-1:8) dan suhu ekstraksi $\left(30-50^{\circ} \mathrm{C}\right)$ terhadap rendemen resin dan karakteristiknya sehingga didapatkan kondisi proses ekstraksi terbaik.

\section{METODE PENELITIAN}

\section{Bahan dan Alat}

Kawasan Hutan Dengan Tujuan Khusus (KHDTK) Carita (Banten) menyuplai buah nyamplung (Calophyllum inophyllum) yangmana cangkangnya digunakan dalam penelitian ini. Bahanbahan kimia seperti metanol, $\mathrm{KI}, \mathrm{H}_{2} \mathrm{SO}_{4}$, etanol, katalis $\mathrm{CuSO}_{4}: \mathrm{Na}_{2} \mathrm{SO}_{4}, \mathrm{Na}_{2} \mathrm{~S}_{2} \mathrm{O}_{3}$, heksan, $\mathrm{NaOH}$, asam borat, larutan Wijs, $\mathrm{KOH}$, indikator mensel dan PP, kloroform, serta bahan-bahan kimia untuk analisis senyawa-senyawa fitokimia secara kualitatif didapatkan dari Sigma-Aldrich dan Brataco (Indonesia) dan merupakan analytical dan technical grade. Labu leher tiga, pendingin balik, hot plate stirrer, termometer, magnetic bar, neraca analitik, blender, oven, tanur, Soxhlet apparatus, labu Kjedhal, cawan porselin dan aluminium, pompa vakum, gelas piala, labu erlenmeyer dan alat gelas lainnya adalah alat-alat yang digunakan dalam penelitian ini.

\section{Metode}

Pengeringan cangkang buah nyamplung pada suhu $60-70^{\circ} \mathrm{C}$ dilakukan sebelum proses ekstraksi resin agar kadar airnya menurun hingga $\leq$ $5 \%$, selain agar pertumbuhan mikroorganisme dan aktivitasnya dalam merusak bahan dapat dihambat. Pengeringan tersebut dilakukan selama 48-72 jam. Karakterisasi cangkang buah nyamplung selanjutnya dilakukan untuk mengetahui kadar-kadar air (AOAC 1995, 950.46), abu (AOAC 1995, 923.03), serat kasar (SNI-01-2891-1992), protein (AOAC 1995, 991.20), resin dan minyak (SNI 01-2891-1992), serta karbohidrat (by difference).

Ekstraksi resin dari cangkang buah nyamplung dilakukan dengan metoda refluks pada suhu $30-50^{\circ} \mathrm{C}$. Tahap ekstraksi diawali dengan penimbangan cangkang buah nyamplung sebanyak $100 \mathrm{~g}$, kemudian ditambahkan ke dalamnya $100 \mathrm{~mL}$ pelarut etanol atau metanol. Campuran bahan dan pelarut selanjutnya digiling dengan blender selama 15 menit. Campuran bahan dan pelarutkemudian dituangkan ke dalam labu dengan tiga leher, dan 500-700 $\mathrm{mL}$ pelarut etanol atau metanol ditambahkan ke dalam campuran tersebut. Ekstraksi dilakukan selama 5 jam pada hot plate stirrer dengan kecepatan pengadukan $800 \mathrm{rpm}$. Campuran pelarut dan resin yang terekstraksi selama proses berlangsung 5 jam diseparasi dari ampas menggunakan vacuumfilter. Pemisahan pelarut dari resin dilakukan dengan evaporator melalui proses evaporasi pada suhu $80^{\circ} \mathrm{C}$. Untuk mengevaporasi seluruh pelarut dari resin selanjutnya dilakukan pemanasan selama 1 jam dalam oven bersuhu $105^{\circ} \mathrm{C}$. Resin yang diperoleh massanya ditimbang dan rendemennya dihitung menggunakan rumus: 
Rendemen $(\%)=[$ massa $\operatorname{resin}(\mathrm{g}) /$ massa bahan (g) $] \times 100$.

Karakterisasi mutu resin dilakukan melalui pengujian kadar total fenol (metode Folin-Ciocalteu yang diadaptasi dari Agbor et al. (2014)), bilangan asam (SNI 04-7182-2006) dan iod (SNI 3748-2006). Senyawa-senyawa fitokimia (flavonoid, alkaloid, tanin, saponin, quinon, steroid, triterpenoid) yang terkandung dalam resin juga dianalisis secara kualitatif dengan metode yang diterangkan oleh Harborne (1996).

Rancangan percobaan acak lengkap dengan 3 faktor, yang meliputi nisbah cangkang terhadap pelarut (1:6 dan 1:8), suhu ekstraksi (30, 40 dan $50^{\circ} \mathrm{C}$ )dan tipe pelarut (etanol dan metanol), digunakan dalam penelitian ini dengan model matematiknya sebagai berikut (Montgomery, 2001).

$$
\begin{aligned}
& \mathrm{Y}_{\mathrm{ijk}}=\mu+\mathrm{A}_{\mathrm{i}}+\mathrm{B}_{\mathrm{j}}+\mathrm{C}_{\mathrm{k}}+(\mathrm{AB})_{\mathrm{ij}}+(\mathrm{AC})_{\mathrm{ik}}+(\mathrm{BC})_{\mathrm{jk}}+ \\
& (\mathrm{ABC})_{\mathrm{ijk}}+\varepsilon_{\mathrm{ijk}} \\
& \mathrm{Y}_{\mathrm{ijk}} \quad=\text { Besaran respon untuk faktor } \mathrm{A} \text { taraf } \\
& \mu \quad=\text { Besaran rata-rata umum } \\
& \mathrm{A}_{\mathrm{i}} \quad=\text { Efek faktor nisbah cangkang } \\
& \mathrm{B}_{\mathrm{j}} \quad=\text { Efek faktor suhu ekstraksi taraf ke- } \mathrm{j} \\
& \mathrm{C}_{\mathrm{k}} \quad=\quad \text { Efek faktor tipe pelarut taraf ke-k } \\
& (\mathrm{AB})_{\mathrm{ij}}=\text { Efek dari interaksi faktor A taraf ke- } \\
& \text { i dan faktor B taraf ke-j } \\
& (\mathrm{AC})_{\mathrm{ik}}=\text { Efek dari interaksifaktor } \mathrm{A} \text { taraf ke-i }
\end{aligned}
$$

Efek error dari faktor A taraf ke-i, faktor B taraf ke-j, faktor Ctaraf ke-k.

\section{HASIL DAN PEMBAHASAN}

Cangkang merupakan bagian dari buah nyamplung, yang menurut Kartika et al. (2017) persentasinya sekitar $60 \%$ dari buah nyamplung (Gambar 1). Tabel 1 memperlihatkan karakteristik cangkang buah nyamplung yang dijadikan bahan baku dalam penelitian ini. Cangkang buah nyamplung hasil pengeringan dengan oven masih mengandung air sekitar 5\%, dan kandungan resinnya cukup tinggi sekitar $10 \%$. Kandungan air dalam bahan yang minim dapat memfasilitasi proses ekstraksi karena pelarut dapat dengan mudah melarutkan resin dari bahan dengan kandungan air yang minim. Sebaliknya kandungan air dalam bahan yang tinggi mengurangi kemampuan pelarut untuk melarutkan resin dari bahan karena perbedaan polaritas antara air dan resin (Amalia Kartika et al. 2018).Oleh karena itu pengeringan bahan sangat penting dilakukan sebelum proses ekstraksi.Selain menurunkan kandungan air dalam bahan, menurut Fadhlullah et al. (2015)pengeringan juga dapat menghentikan aktivitas enzim dalam merusak bahan, serta pertumbuhan mikroorganisme dan aktivitasnya.

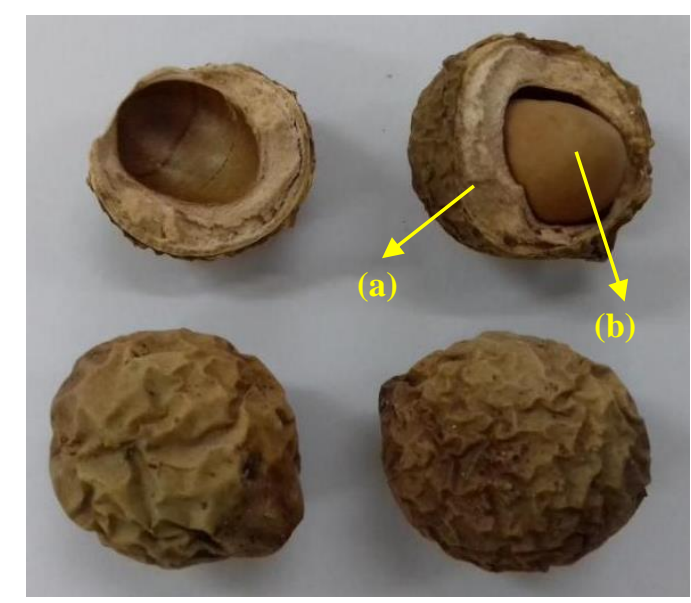

Gambar 1. Morfologi buah nyamplung (a) cangkang, (b) biji

Berdasarkan Tabel 1 cangkang buah nyamplungdidominasi oleh serat $(68,1 \%)$, yang menurut Senthil dan Mohan (2015) terdiri atas hemiselulosa, selulosa dan lignin, sehingga pemanfaatan cangkang buah nyamplunguntuk bahan baku dalam produksi arang aktif (Wibowo et al., 2010), pupuk organik, papan partikel dan briket (Almu et al., 2014) juga prospektif. Selain itu, kadar protein dan abunya yang rendah menjadikan cangkang buah nyamplung rendah emisi gas $\mathrm{NO}_{\mathrm{x}}$ dan rendah kerak sisa pembakaran ketika digunakan sebagai briket (Faizal et al., 2015). Kadar minyaknya yang cukup tinggi $( \pm 9 \%)$ juga dapat menguntungkan pemanfaatannya sebagai briket, yaitu dapat meningkatkan nilai kalornya.

Tabel 1. Karakteristik cangkang buah nyamplung

\begin{tabular}{lc}
\hline \multicolumn{1}{c}{ Parameter } & Nilai $(\%$ bb $)$ \\
\hline Kadar resin & $10,21 \pm 0,16$ \\
Kadar air & $4,99 \pm 0,02$ \\
Kadar abu & $2,36 \pm 0,20$ \\
Kadar lemak & $9,17 \pm 0,27$ \\
Kadar protein & $1,54 \pm 0,15$ \\
Kadar serat & $68,07 \pm 0,62$ \\
Kadar karbohidrat $(b y$ & $13,90 \pm 1,30$ \\
difference $)$ & \\
\hline
\end{tabular}


Proses ekstraksi cangkang buah nyamplung yang dilakukan dalam penelitian ini menghasilkan resin yang berwarna coklat gelap dan kental (Gambar 2). Rendemen resin yang dihasilkan berkisar antara 2-8\% dengan kadar total fenol 33-72 mg ekuivalen asam galat/kgdan bilangan asam 112$146 \mathrm{mg} \mathrm{KOH} / \mathrm{g}$. Bilangan iod resin berkisar antara 55-57 mg iodin/g, dan resin positif mengandung saponin. Kandungannya terhadap senyawa-senyawa seperti flavonoid, alkaloid, tanin, quinon, steroid dan triterpenoid adalah negatif.

Hasil sidik ragam untuk rendemen resin (Tabel 2) memperlihatkan bahwa nisbah cangkang terhadap pelarut (A)dan suhu ekstraksi (B) berpengaruh secara nyata pada rendemen resin sedangkan tipe pelarut (C) tidak berpengaruh nyata. Rendemen resin yang diperoleh dari perlakuan ekstraksi dengan pelarut etanol nilainya relatif sama dengan yang diekstraksi pelarut metanol. Kinerja etanol dan metanol dalam mengekstraksi resin dari cangkang buah nyamplung relatif sama. Berdasarkan uji lanjut Duncan, rendemen resin dapat ditingkatkan secara siginifikan dengan peningkatan nisbah cangkang terhadap pelarut dan suhu ekstraksi (Tabel 3). Rendemen resin tertinggi (7,69\%) dengan demikian dapat diperoleh dariperlakuan nisbah cangkang terhadap pelarut terbesar (1:8) dan suhu ekstraksi tertinggi $\left(50^{\circ} \mathrm{C}\right)$.

Tabel 3 memperlihatkan bahwa semakin besar nisbah cangkang terhadap pelarut, rendemen resin semakin tinggi. Perpindahan massa antara pelarut dengan zat terlarut dan juga luas kontak permukaan bahan akan semakin besardengan semakin banyak pelarut yang digunakan sehingga akan semakin banyak pula zat terlarut yang dapat diekstraksi oleh pelarut (Yulviyanti et al., 2014; Tagora et al., 2012). Menurut Geankoplis (1993) perpindahan massa akan terjadi jika konsentrasi antara zat terlarut dalam bahan dan pelarut berbeda, dan perpindahan tersebut akan berakhir ketika konsentrasi zat terlarut pada keduanya telah seimbang. Dalam proses ekstraksi makin banyak pelarut yang ditambahkan, maka perbedaan konsentrasi antara pelarut dengan zat terlarut yang terkandung dalam bahan makin besar pula sehingga makin banyak zat terlarut yang dapat diekstraksi oleh pelarut.

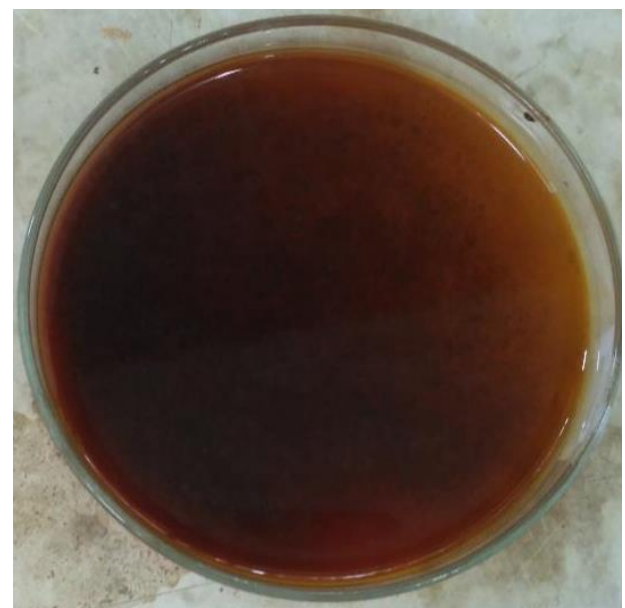

Gambar 2. Resin hasil ekstraksi cangkang buah nyamplung dengan alcohol

Selain jumlah pelarut, pada penelitian ini rendemen resinjuga dapat ditingkatkan secara signifikan dengan ditingkatkannya suhu ekstraksi setinggi $10^{\circ} \mathrm{C}$. Peningkatan kelarutan dan kecepatan transfer massa resin ke dalam pelarut, serta penurunan viskositas resin dan tegangan permukaan pelarut dapat terjadi apabila suhu yang lebih tinggi diterapkan dalam proses esktraksi sehingga resin lebih mudah terekstraksi (Kartika et al., 2018). Peningkatan suhu, menurut Evon et al. (2007), juga dapat meningkatkan pelarutan zat terlarut oleh pelarut di dalam sel dan laju difusi pelarut ke dalam pori-pori bahan padat atau dinding sel akibat mengembangnya pori-pori padatan.

Selain meningkatkan rendemen, peningkatan suhu juga dapat mempercepat proses ekstraksi akibat adanya percepatan laju difusi (Margaretta et al., 2011; Abu-arabi et al., 2000), dan meningkatkan efisiensinya akibat energi kinetiknya meningkat sehingga resin yang terkandung di dalam sel meningkat solubilitasnya dalam pelarut dan pemisahan resin yang terikat oleh daya tarik antar molekul menjadi lebih mudah (Ashgari et al., 2011).

Tabel 2. Nilai $F$ hasil dari sidik ragam untuk rendemen dan mutu resin

\begin{tabular}{lcccc}
\hline \multicolumn{1}{c}{ Sumber keragaman } & $\begin{array}{c}\text { Nilai F untuk } \\
\text { rendemen }\end{array}$ & $\begin{array}{c}\text { Nilai F untuk } \\
\text { bilangan asam }\end{array}$ & $\begin{array}{c}\text { Nilai F untuk } \\
\text { kadar total fenol }\end{array}$ & $\begin{array}{c}\text { Nilai Fpada } \boldsymbol{\alpha} \\
\mathbf{= 0 , 0 5}\end{array}$ \\
\hline Nisbah cangkang terhadap & $10,5808^{*}$ & $17,00^{*}$ & $7,525^{*}$ & 4,75 \\
pelarut (A) & $66,153^{*}$ & 1,824 & $29,399^{*}$ & 3,89 \\
Suhu ekstraksi (B) & 0,146 & $31,118^{*}$ & $6,462^{*}$ & 4,75 \\
Tipe pelarut (C) & 2,041 & $4,647^{*}$ & 1,062 & 3,89 \\
Interaksi antara AB & $77,913^{*}$ & 1,471 & 0,521 & 4,75 \\
Interaksi antara AC & $5,056^{*}$ & $18,059^{*}$ & $6,827^{*}$ & 3,89 \\
Interaksi antara BC & $4,570^{*}$ & 1,118 & $6,240^{*}$ & 3,89 \\
Interaksi antara ABC & & & & \\
\hline
\end{tabular}

\footnotetext{
*Signifikan
} 
Resin yang didapatkan dari penelitian ini rendemennya (7,69\%) lebih kecil dibandingkan dengan yang didapatkan dari proses ekstraksi biji nyamplung menggunakan metanol $(17,7 \%)$ (Kartika et al., 2018), meskipun nisbah cangkang terhadap pelarut yang digunakan lebih tinggi (1:8 vs 1:4), tipe pelarut yang digunakan sama (metanol), suhu dan waktu ekstraksi juga sama $\left(50^{\circ} \mathrm{C}\right.$ dan 5 jam). Namun apabila rendemen dihitung berdasarkan massa resin potensial yang terkandung dalam bahan (Tabel 3), rendemen resin yang diperoleh dari penelitian ini lebih tinggi sekitar $14 \%$ dari yang diperoleh oleh Kartika et al. (2018) (75,32\% vs 61,46\%).

Penggunaan tipe pelarut etanol dan metanol pada studi ini tidak berpengaruh secara nyata pada rendemen resin. Pelarut umumnya akan melarutkan zat terlarut yang memiliki kelarutan yang sama. Berdasarkan parameter kelarutan Hildebrand $(\delta)$, resin (fenol pada umumnya) memiliki nilai $\delta$ sekitar 21-29 $\mathrm{MPa}^{1 / 2}$, sedangkan nilai $\delta$ untuk metanol danetanol masing-masing adalah $29,7 \mathrm{MPa}^{1 / 2}$ dan 26,2 $\mathrm{MPa}^{1 / 2}$ (Burke, 1984). Nilai $\delta$ metanol, dan etanol yang relatif sama dan kecocokan nilai $\delta$ keduanya dengan nilai $\delta$ resin menyebabkan keduanya dapat mengekstraksi resin dengan rendemen yang tidak berbeda nyata (Kartika et al., 2018).

Meskipun pengaruhnya terhadap rendemen tidak signifikan, namun tipe pelarut berpengaruh secara signifikan terhadap mutu resin yang dihasilkan, khususnya bilangan asam dan kadar total fenol. Berdasarkan hasil sidik ragam untuk bilangan asam (Tabel 2), hanya nisbah cangkang terhadap pelarut (A) dan tipe pelarut (C) saja yang berpengaruh secara signifikan pada bilangan asam, sedangkan suhu ekstraksi tidakberpengaruh secara signifikan. Hasil uji lanjut Duncan menunjukkan bilangan asam resin yang diekstraksi dengan pelarut etanol lebih tinggi daripada dengan pelarut metanol, dan peningkatan nisbah bahan terhadap pelarut dapat meningkatkan bilangan asam resin. Hal ini menunjukkan bahwa resin yang diekstraksi dengan pelarut etanol lebih banyak mengandung senyawasenyawa asam dibandingkan dengan metanol, dan semakin tinggi nisbah bahan terhadap pelarut bilangan asam resin pun semakin tinggi. Senyawasenyawa asam yang terkandung dalam resin kemungkinan memiliki kepolaran yang lebih dekat dengan etanol daripada metanol sehingga kandungannya dalam resin yang diekstraksi dengan etanol lebih tinggi dibandingkan dengan metanol.

Berdasarkan hasil-hasil penelitian sebelumnya, keasaman resin sangat tinggi karena resin nyamplung banyak mengandung asam kalofilat (calophyllic acid), asam begonia dan kalofinat, fenol dan polifenol, senyawa-senyawa turunan asam sinamat (Liu et al., 2015), serta asam benzoat (Prabakaran dan Britto, 2012). Sifat asam dan senyawa-senyawa tersebut yang polar dan larut dalam metanol dan etanol menyebabkannya mudah diekstraksi oleh metanol dan etanol. Asam kalofilat (calophyllic acid) merupakan asam organik yang memiliki aktivitas antibiotik (Dweck dan Meadow, 2002).

Nisbah cangkang terhadap pelarut 1:8 menghasilkan bilangan asam resin yang lebih tinggi dari pada nisbah 1:6. Hal ini sesuai dengan prinsip perpindahan massa yang sudah diterangkan sebelumnya dimana makin banyak pelarut yang ditambahkan maka zat terlarut yang larut dalam pelarut pun makin banyak. Dibandingkan dengan resin yang diekstraksi dari biji nyamplung (Kartika et al.,2018), resin yang didapatkan dari penelitian ini mempunyai bilangan asam yang lebih rendah (112$146 \mathrm{mg} \mathrm{KOH} / \mathrm{g}$ vs $159-195 \mathrm{mg} \mathrm{KOH} / \mathrm{g}$ ). Fenomena ini mungkin terjadi karena resin yang diekstraksi dari biji nyamplung selain mengandung asam-asam organik, juga banyak mengandung asam-asam lemak bebas, contohnya asam oleat, palmitat, stearat danl inoleat. Asam-asam lemak bebas tersebut lebih mudah dan banyak terlarut dalam etanol dan metanol sebagai pelarut polar dibandingkan pelarut non polar (heksan) sehingga pada ekstraksi biji nyamplung menggunakankedua pelarut polar dan non polar asam lemak bebas akan lebih banyak terikut pada fraksi resin dibandingkan fraksi minyak (Kartika et al.,2018). Dibandingkan dengan kopal (Ando dan Wiyono, 1988), bilangan asam resin yang didapat dari penelitian ini relatif sama (112-146 mg KOH/g vs $100-145 \mathrm{mg} \mathrm{KOH} / \mathrm{g}$ ). Menurut Dweck dan Meadow (2002), resin dari nyamplung juga mirip dengan resin dari kemenyan.

Pengaruh nisbah cangkang terhadap pelarut (A), suhu ekstraksi (B) dan tipe pelarut (C) pada kadar total fenol resin berdasarkan hasil sidik ragam adalah signifikan (Tabel 2). Kadar total fenol resin berdasarkan hasil uji lanjut Duncan dapat ditingkatkan dengan peningkatan nisbah cangkang terhadap pelarut, penurunan suhu ekstraksi dan penggunaan metanol sebagai pelarut. Kadar total fenol tertinggi (71.23 mg ekuivalen asam galat $/ \mathrm{kg}$ ) dengan demikian dapat diperoleh dari perlakuan nisbah cangkang terhadap metanol 1:8, suhu ekstraksi $30^{\circ} \mathrm{C}$ dantipe pelarut metanol (Tabel 3).

Menurut Harborne (1996), fenol adalah senyawa kimia alami yang mempunyai cincin aromatik dengan satu atau dua gugus hidroksil. Flavanoid, tanin, terpenoid dan alkaloidadalah contoh senyawa-senyawa fenol.Fenol mudah terdegradasi oleh panas sehingga penggunaan suhu yang tinggi dapat menurunkan kadar total fenol (Spignoet al., 2007). Suhu degradasi senyawasenyawa fenolik berbeda-beda untuk setiap jenis bahan (Lin dan Chen, 2007; Chew et al., 2011), dan pada penelitian ini kadar total fenol resin menurun secara signifikan ketika suhu ekstraksi ditingkatkan dari $30^{\circ} \mathrm{C}$ ke $50^{\circ} \mathrm{C}$. Hal ini menunjukkan senyawasenyawa fenolik yang terkandung dalamresin yang diekstraksi dari cangkang buah nyamplung dapat terdegradasi dengan kenaikan suhu $10^{\circ} \mathrm{C}$ saja. 
Tabel 3. Rendemen dan mutu resin yang didapatkan dari proses ekstraksi cangkang buah nyamplung pada perlakuan yang berbeda-beda

\begin{tabular}{ccccccc}
\hline $\begin{array}{c}\text { Nisbah } \\
\text { bahan } \\
\text { terhadap } \\
\text { pelarut }\end{array}$ & $\begin{array}{c}\text { Suhu } \\
\left({ }^{\circ} \mathbf{C}\right)\end{array}$ & $\begin{array}{c}\text { Tipe } \\
\text { pelarut }\end{array}$ & $\begin{array}{c}\text { Rendemen } \\
\text { basis massa } \\
\text { bahan }(\boldsymbol{\%})\end{array}$ & $\begin{array}{c}\text { Rendemen } \\
\text { basis massa } \\
\text { resin potensial } \\
\mathbf{( \% )}\end{array}$ & $\begin{array}{c}\text { Bilangan asam } \\
\text { (mg KOH/g) }\end{array}$ & $\begin{array}{c}\text { Kadar total fenol } \\
\text { (mg ekuivalen } \\
\text { asam galat/kg) }\end{array}$ \\
\hline $1: 6$ & 30 & Etanol & $3,56 \pm 0,27$ & $34,87 \pm 0,27$ & $129,03 \pm 5,61$ & $67,96 \pm 2,24$ \\
$1: 6$ & 40 & Etanol & $4,69 \pm 0,35$ & $45,94 \pm 0,35$ & $131,83 \pm 2,80$ & $43,15 \pm 4,61$ \\
$1: 6$ & 50 & Etanol & $5,92 \pm 0,30$ & $57,98 \pm 0,30$ & $117,81 \pm 5,61$ & $50,40 \pm 5,96$ \\
$1: 6$ & 30 & Metanol & $2,41 \pm 0,41$ & $23,60 \pm 0,41$ & $112,20 \pm 0,05$ & $69,24 \pm 6,47$ \\
$1: 6$ & 40 & Metanol & $2,83 \pm 0,19$ & $27,72 \pm 0,19$ & $112,20 \pm 0,01$ & $70,59 \pm 6,92$ \\
$1: 6$ & 50 & Metanol & $4,47 \pm 0,27$ & $43,78 \pm 0,27$ & $129,03 \pm 5,61$ & $45,59 \pm 2,05$ \\
$1: 8$ & 30 & Etanol & $3,21 \pm 0,07$ & $31,44 \pm 0,07$ & $145,86 \pm 0,01$ & $52,70 \pm 4,93$ \\
$1: 8$ & 40 & Etanol & $3,43 \pm 0,16$ & $33,59 \pm 0,16$ & $140,25 \pm 5,61$ & $53,29 \pm 2,43$ \\
$1: 8$ & 50 & Etanol & $4,59 \pm 0,19$ & $44,96 \pm 0,19$ & $123,42 \pm 0,03$ & $40,72 \pm 1,41$ \\
$1: 8$ & 30 & Metanol & $4,11 \pm 0,11$ & $40,25 \pm 0,11$ & $123,42 \pm 0,02$ & $71,23 \pm 3,08$ \\
$1: 8$ & 40 & Metanol & $4,27 \pm 0,27$ & $41,82 \pm 0,27$ & $123,42 \pm 0,01$ & $55,72 \pm 3,97$ \\
$1: 8$ & 50 & Metanol & $7,69 \pm 0,62$ & $75,32 \pm 0,62$ & $123,42 \pm 0,04$ & $33,09 \pm 1,09$ \\
\hline
\end{tabular}

Fenomena ini berbanding terbalik dengan rendemen resin yang mengalami peningkatan secara signifikan dengan peningkatan suhu $10^{\circ} \mathrm{C}$. Ekstraksi resin dari cangkang buah nyamplung pada suhu $50^{\circ} \mathrm{C}$ dapat menghasilkan rendemen tertinggi $(7,69 \%)$ tetapi kadar total fenolnya rendah $(33,09 \mathrm{mg}$ ekuivalen asam galat $/ \mathrm{kg}$ ), dan sebaliknya ekstraksi resin pada suhu $30^{\circ} \mathrm{C}$ dapat menghasilkan kadar total fenol tertinggi $(71,23 \mathrm{mg}$ ekuivalen asam galat $/ \mathrm{kg}$ ) tetapi rendemennya rendah $(4,11 \%)$.

Penggunaan pelarut metanol pada ekstraksi resin dari cangkang buah nyamplung menghasilkan kadartotal fenol yang lebih besardaripada dengan pelarut etanol, dan semakin tinggi nisbah bahan terhadap pelarut semakin tinggi pula kadar total fenol resin. Perbedaan kadar total fenolini kemungkinan disebabkan oleh perbedaan polaritas antara etanol dan metanol dimana etanol mempunyai polaritas lebih tinggi daripada metanol. Etanol mempunyai indeks polaritas sebesar 5,2, sedangkan indeks polaritas metanol sebesar 5,1 (Burke, 1984). Berdasarkan hasil-hasil penelitian sebelumnya (Chew et al., 2011; Madani dan Mokrani, 2016; Zlotek et al., 2016), senyawa-senyawa fenolik lebih banyak terekstraksi oleh pelarut dengan polaritas lebih rendah seperti aseton dan metanol dibandingkan etanol dan air. Fenomena ini berbanding terbalik dengan senyawa-senyawa asam yang lebih banyak terekstraksi oleh pelarut dengan kepolaran lebih tinggi seperti etanol dibandingkan metanol. Kadar total fenol resin yang diperoleh dari riset ini (33-72 mg ekuivalen asam galat $/ \mathrm{kg}$ ) jauh lebih rendah daripada yang diperoleh dari biji nyamplung (40000-60000 mg ekuivalen asam galat/kg) (Kartika et al., 2018). Hal ini menunjukkan kandungan senyawa-senyawa fenolik dalam biji nyamplung lebih tinggi daripada dalam cangkang buah nyamplung. Selain itu, penggunaan pelarut biner (campuran polar dan non polar) pada ekstraksi biji nyamplung memungkinkan senyawa-senyawa fenolik lebih banyak terekstraksi dibandingkan menggunakan pelarut polar saja karena polaritas pelarut biner lebih rendah daripada pelarut polar.

Berdasarkan hasil terbaik dari rendemen dan kadar total fenol resin, pada penelitian ini dipilih 2 perlakuan terbaik, yaitu A2B3C2 (nisbah cangkang terhadap pelarut $1: 8$, suhu $50^{\circ} \mathrm{C}$, tipe pelarut metanol) yang menghasilkan rendemen resin tertinggi dan A2B1C2 (nisbah cangkang terhadap pelarut 1:8, suhu $30^{\circ} \mathrm{C}$, tipe pelarut metanol) yang menghasilkan kadar total fenol resin tertinggi, untuk dianalisis lebih lanjut kandungan senyawa-senyawa fitokimia (flavonoid, alkaloid, tanin, saponin, quinon, steroid, triterpenoid) dan bilangan iodnya. Pada Tabel 4 dapat dilihat bahwa resin yang dihasilkan dari kedua perlakuan ini hanya positif mengandung saponin. Saponin merupakan glikosida sterol dan triterpen (Harborne,1987). Saponin memiliki sifat seperti sabun dan kemampuan menghemolisis darah. Selain itu, saponin memiliki beberapa kemampuan lainnya seperti cytotoxicity, antiinflammatory, antimikroba, antioksidan, phytotoxicity dan molluscida activity (Sidana et al., 2016). Saponin juga memiliki aktifitas pengahambatan tumor dan menurunkan kolestrol (Susanto et al., 2017). Kandungan saponin dengan kemampuannya yang besar dalam resin yang diekstraksi dari cangkang buah nyamplung memungkinkan pemanfaatannya untuk keperluan non pangan, seperti produk-produk kosmetika dan pharmasi (Ashgari et al., 2011; Dai dan Mumper, 2010; Athari dan Nasir, 2004).

Atas dasar Tabel 4, resin yang dihasilkan dari kedua perlakuan ini memiliki bilangan iod yang sama. Hal ini menunjukkan kandungan senyawasenyawa yang memiliki ikatan rangkap pada resin yang dihasilkan dari kedua perlakuan ini relatif sama. Menurut Harborne (1996), ikatan rangkap yang terukur dalam bilangan iod dapat berasal dari asam-asam organik, asam-asam lemak dan senyawasenyawa lainnya. 
Tabel 4. Karakteristik resin hasil ekstraksi dari cangkang buah nyamplung dengan dua perlakuan terbaik

\begin{tabular}{lcc}
\hline \multicolumn{1}{c}{ Parameter } & $\begin{array}{c}\text { Perlakuan nisbah bahan } \\
\text { terhadap pelarut 1:8, suhu } \\
\mathbf{5 0}^{\circ} \mathbf{C} \text {, tipe pelarut metanol }\end{array}$ & $\begin{array}{c}\text { Perlakuan nisbah bahan } \\
\text { terhadap pelarut 1:8, suhu } \\
\mathbf{3 0}^{\circ} \mathbf{C} \text {, tipe pelarut metanol }\end{array}$ \\
\hline $\begin{array}{l}\text { Rendemen(\%) } \\
\text { Kadar total fenol (mg ekuivalen asam } \\
\text { galat/kg) }\end{array}$ & $7,69 \pm 0,62$ & $4,11 \pm 0,11$ \\
Bilangan iod (g iodin/100 g) & $33,09 \pm 1,09$ & $71,23 \pm 3,08$ \\
Bilangan asam (mg KOH/g) & $56,33 \pm 0,10$ & \\
Flavonoid & $123,42 \pm 0,04$ & $56,33 \pm 0,10$ \\
Alkaloid & $(-)$ negatif & $123,42 \pm 0,02$ \\
Tanin & $(-)$ negatif & $(-)$ negatif \\
Saponin & $(-)$ negatif & $(-)$ negatif \\
Quinon & $(+)$ positif & $(-)$ negatif \\
Steroid & $(-)$ negatif & $(+)$ positif \\
Triterpenoid & $(-)$ negatif & $(-)$ negatif \\
\hline
\end{tabular}

\section{KESIMPULAN DAN SARAN}

\section{Kesimpulan}

Pengaruh nisbah cangkang terhadap pelarut dan suhu sangat signifikan pada rendemen dan karakteristik resin yang diekstraksi dari cangkang buah nyamplung, sedangkan jenis pelarut hanya berpengaruh signifikan pada karakteristik resin. Nisbah cangkang terhadap pelarut 1:8 dan suhu $50^{\circ} \mathrm{C}$ dengan metanol sebagai pelarut menghasilkan rendemen resin terbaik $(7,69 \%$ atau $75,32 \%$ basis massa resin potensial yang dikandung bahan). Pada kondisi proses optimal resin yang didapatkan memiliki kadar total fenol 33,09 mg ekuivalen asam galat/kg,bilangan iod 56,33 g iodin/100 g,bilangan asam 123,42 $\mathrm{mg} \mathrm{KOH} / \mathrm{g}$, dan resin positif mengandung saponin. Dengan demikian cangkang buah nyamplung pemanfaatannya sangat prospektif sebagai penghasil resin alami.

\section{Saran}

Untuk meningkatkan rendemen resin, nisbah cangkang terhadap pelarut perlu ditingkatkan nilainya. Selain itu resin yang dihasilkan perlu dikarakterisasi lebih lanjut, khususnya kemampuannya sebagai antimikroba dan antioksidan.

\section{UCAPAN TERIMA KASIH}

Terima kasih penulis ucapkan kepada KEMENRISTEKDIKTI khususnya Direktorat Riset dan Pengabdian Masyarakat, Direktorat Jenderal Penguatan Riset dan Pengembangan untuk dukungan dana (Penelitian Kompetitif Nasional, Skema Penelitian Terapan dengan nomor kontrak 4297/IT3.L1/PN/2019) dalam pelaksanaan penelitian ini.

\section{DAFTAR PUSTAKA}

Abu-Arabi MK, Allawzi MA, Al-Zoubi HS, Tamimi A. 2000. Extraction of jojoba oil by pressing and leaching. Chemical Engineering Journal 76:61-65.

Agbor G, Vinson J, Donnelly PE. 2014. FolinCiocalteu reagent for polyphenolic assay. International Journal of Food Science, Nutrition and Dietetics 3(8): 147-156.

Almu M, Syahrul, Padang YA. 2014. Analisa nilai kalor dan laju pembakaran pada briket campuran biji nyamplung (Calophyllum inophyllum) dan abu sekam. Dinamika Teknik Mesin 4(2):117-122.

Amalia Kartika I, Cerny M, Vandenbossche V, Rigal L, Sablayrolles C, Vialle C, Suparno O, Ariono D, Evon Ph. 2018. Direct Calophyllum oil extraction and resin separation with a binary solvent of $n$ hexane and methanol mixture. Fuel. 221:159-164.

Ando Y dan Wiyono B. 1988. Sifat-sifat kopal manila dari Pekalongan Timur dan Banyumas Barat. Jurnal Penelitian Hasil Hutan5(6):353-356.

Ashgari J, Ondruschka B, Mazaheritehrani M. 2011. Extraction of bioactive chemical compounds from the medicinal asian plants by microwave irradiation. Journal of Medicinal Plants Research 5(4):495-506.

Assagaf M, Hastuti P, Hidayat C, Supriyadi. 2012. Optimasi ekstraksi oleoresin pala (Myristica fragrans Houtt) asal Maluku Utara menggunakan response surface methodology (RSM). Agritech 32(1):383390.

Atabani AE dan César AS. 2014. Calophyllum inophyllum L.-A prospective non-edible biodiesel feedstock. Study of biodiesel production, properties, fatty acid composition, blending and engine performance. Renewable and Sustainable Energy Reviews 37:644-655.

Athari M dan Nasir SM. 2004. Taxonomic perspective of plant species yielding vegetable oils used in cosmetics and skin 
care product. Africal Journal of Biotechnology 4(1):36-44.

Burke J. 1984. Solubility Parameters: Theory and Application. The American Institute forConservation.

Bustomi S, Rostiwati R, Sudrajat R, Kosasih S, Anggraini I, Leksono B, et al. 2008. Nyamplung (Calophyllum inophyllum L) Sumber Energi Biofuel Yang Potensial. Bogor (ID): Badan Litbang Kehutanan.

Chew KK, Khoo MZ, Ng SY, Thoo YY, Wan Aida WM, Ho CW. 2011. Effect of ethanol concentration, extraction time and extraction temperature on the recovery of phenolic compounds and antioxidan capacity of Orthosiphon stamineus exracts. International Food Research Journal. 18(4):1427-1435.

Dai J dan Mumper RJ. 2010. Plant phenolic: Extraction, analysis and their antioxidant and anticancer properties. Molecules 15(10):7313-7352.

Dweck AC dan Meadows T. 2002. Tamanu (Calophyllum inophyllum)-The African, Asian, Polynesian and Pacific Panacea. International Journal of Cosmetic Science 24:1-8.

Evon P, Vandenbossche V, Pontalier PY, Rigal L. 2007. Direct extraction of oil from sunflower seeds by twin-screw extruder according to an aqueous extraction process: Feasibility study and influence of operating conditions. Industrial Crops and Products 26:351-359.

Fadhlullah M, Widiyanto SNB, Elvi Restiawaty E. 2015. The potential of nyamplung (Calophyllum inophyllum L.) seed oil as biodiesel feedstock: Effect of seed moisture content and particle size on oil yield. Energy Procedia 68:177-185.

Faizal M, Saputra M, Zainal FA. 2015. Pembuatan briket bioarang dari campuran batubara dan biomassa sekam padi dan enceng gondok. Jurnal Teknik Kimia4(21):27-38.

Frial-McBride. 2016. Extraction of resin from Capsicum annum var. longum (Siling haba) for the study of their potensial antimicrobial activities. Journal of Chemical and Pharmaceutical Research8 (3):117-127.

Geankoplis CJ. 1993. Transport Processes and Unit Operations. London: Prentice-Hall International, Inc.

Harborne JB. 1996. Metode Fitokimia: Penuntun Cara Modern Menganalisis Tumbuhan. Cetakan Kedua. Terjemahan. Padmawinata K dan Soediro I. Bandung: Penerbit ITB.

Jain M, Chandrakant U, Orsat V, Raghavan V. 2018. A review on assessment of biodiesel production methodologies from
Calophyllum inophyllum seed oil. Industrial Crops and Products 114:28-44.

Kartika IA, Sari DDK, Pahan AF, Suparno O, Ariono D. 2017. Ekstraksi minyak dan resin nyamplung dengan campuran pelarut heksan-etanol. Jurnal Teknologi Industri Pertanian27(2):161-71.

Leksono B, Hendrati RL, Windyarini E, Hasnah T. 2014. Variation of biofuel potential of 12 Calophyllum inophyllum populations in Indonesia.Indonesian Journal of Forestry Research 1(2):127-138.

Lin KI dan Chen YT. 2007. Effect of heating temperature on the total phenolic compound, antioxidative ability and the stability of dioscorin of various yam cultivars. Food Chemistry101:955-963.

Liu W, Liu Y, Chen Z, Chiou W, Tsai Y, Chen C. 2015. Calophyllolide content in Calophyllum inophyllum at different stage of maturity and its osteogenic activity. Molecules 20(7):12314-12327.

Margaretta S, Handayani SD, Indraswati N, Hindarso H. 2011. Ekstraksi senyawa phenolik Pandanus amaryllifolius Roxb sebagai antioksidan alami. Widya Teknik 10(1):21-30.

Madani K dan Mokrani A. 2016. Effect of solvent, time, temperatureon the extraction of phenolic compounds and antioxidant capacity of peach (Prunus persica L.) fruit. Separation and Purification Technology162:68-76.

Montgomery DC. 2001. Design and Analysis of Experimental $5^{\text {th }}$ Edition. New York: John Wiley and Son.

Prabakaran K dan Britto SJ. 2012. Biology, agroforestry and medicinal value of Calophyllum inophyllum L. (clusiacea): A review. International Journal of Natural Product Research 1(2):24-33.

Senthil R dan Mohan K. 2015. Comparison of yield and fuel properties of thermal and catalytic Calophyllum inophyllum seed sheel pyrolytic oil. Journal of Chemical and Pharmaceutical Sciences 9:119-126.

Sidana J, Singh B, Sharma OMP. 2016. Saponin of agave: Chemistry and bioactivity. Phytochemistry. 130:22-46.

Spigno G, Tramelli L, Faveri DMD. 2007. Effects of extraction time temperature and solvent on concentration and antioxidant activity of grape marc phenolics. Journal of Food Engineering 81:200-208.

Susanto DF, Aparamarta HW, Widjaja A, Gunawan S. 2017. Identification of phytochemical compounds in Calophyllum inophyllum leaves. Asian Pacific Journal Tropical Biomedicine 7(9):773-781. 
Swern D (Ed). 1982. Bailey’s Industrial Oil and Fat Products4th Edition. New York: John Wiley and Sons.

Tagora BPS, Sirait R, Iriany. 2012. Penentuan kondisi keseimbangan unit leaching pada produksi eugenol dari daun cengkeh. Jurnal Teknik Kimia USU 1(1):10-14.

Tempesta MS.1993. Proanthocyanidin polymers having anti viralactivity and method sofobtaining same. US Patent. US005211944A.

Wibowo S, Syafii W, Pari G. 2010. Karakteristik arang aktif tempurung biji nyamplung (Calophyllum inophyllum). Jurnal Penelitian Hasil Hutan 28(1):43-54.
Yulviyanti M, Sari RM, Amaliah ER. 2014. Pengaruh perbandingan campuran pelarut n-heksan-etanol terhadap kandungan sitronelal hasil ekstraksi sereh wangi (Cymbopogon nardus). Jurnal Integrasi Proses 5(1):8-14.

Zlotek U, Mikulska S, Nagajek M, Swieca M. 2016. The effect of different solvents and number of extraction steps on the polyphenol content and antioxidant capacity of basil leave (Ocimum basilicum L.) extracts. Saudi Journal of Biological Science. 23:628-633. 